\title{
GERAKAN MAHASISWA DI INDONESIA DALAM BINGKAI KEKUASAAN ORDE BARU (1966-1998)
}

\author{
Oleh: Mohammad Maiwan*
}

\begin{abstract}
This study discusses the dynamics of Indonesian student movement in the New Order era between 1966 until 1998. It also analyses the responses of the authority to their movement and its impact. This research uses the qualitative method of literature review and interviews where the arguments are presented in descriptive analysis. Based on Antonio Gramsci's concept of hegemony, this study has uncovered the hegemonic means utilized by the authority to undermine student movement. The description of how this social formation was defragmented, justified and then integrated into bureaucratic processes where their existence was then consented as a subordinated class. In reality, the student movement under the New Order government was closely related to the situation of socio-politics and character of the regime. Nevertheless, the Asian economic crisis jolted the revival of the student movement to its initial vibrant state which brought down Suharto's regime in 1998. This study has proven that hegemonic process also has a shelflife as the masses will eventually see through the regime's political construction. This eventuality was due to external and internal factors such as development of information technology, the rise of cyber-power, international politics and the emergence of new ideas.
\end{abstract}

Key Words: Student, politics, movement.

Pendahuluan

$$
\text { Gerakan mahasiswa merupakan }
$$
salah satu fenomena menarik di sejumlah negara berkembang yang menandai adanya bentuk aktifisme politik di kalangan terdidik. Meskipun kebanyakan di antara mereka bagian dari kelas sosial yang mapan, namun penentangan mereka terhadap sistem yang berlaku menunjukkan bahwa kelompok ini memiliki nilai dan orientasi yang berbeda dari lapisan mana mereka berasal. Dalam beberapa kasus, kita menyaksikan berbagai perubahan politik yang berlangsung di sejumlah adanya aktifisme mahasiswa. Meskipun mereka bukan merupakan kekuatan politik formal, namun sampai tahap tertentu, gerakan mahasiswa telah berhasil mempengaruhi situasi politik, dengan melakukan tekanan-tekanan terhadap sistem politik. Sebagai kelompok minoritas terdidik dalam suatu masyarakat yang sedang membangun, mahasiswa sesungguhnya memiliki pengaruh yang cukup diperhitungkan.

Mereka bukan hanya menjadi sumber tenaga pembangunan, tetapi juga sumber rekruitmen kepemimpinan dalam

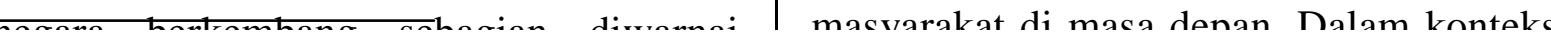
*Dosen Program Studi Pendidikan Pancasila dan Kewarganegaraan Jurusan Ilmu Sosial Politik, Fakultas Ilmu Sosial Universitas 
negara berkembang, sesungguhnya mahasiswa memiliki posisi yang strategis dalam kehidupan bangsa. Di samping memiliki kewajiban mencari ilmu pengetahuan, mereka juga bertanggungjawab untuk menumbuhkan perubahan sosial sekaligus mendorong perubahan politik. Mahasiswa adalah "cabang keempat" dari pemerintahan dan kampus menduduki posisi penting dalam sistem politik (Altbach 1988: 7).

Beberapa gerakan mahasiswa di sejumlah negara, telah berhasil mempengaruhi proses politik, sehingga memungkinkan berlakunya berbagai perubahan. Bahkan pada masa lalu gerakan mahasiswa di Korea Selatan, Turki, Vietnam Selatan, Bolivia, Venezuela, Thailand, Jepang dan beberapa negara lainnya telah memainkan peran dalam menggulingkan pemerintah (Lipset 1967: vii). Begitu juga dengan beberapa gerakan mahasiswa yang lain seperti: di Burma, Nigeria, Brasil, Filipina, Polandia, China, bersama sebagian kelompok masyarakat yang lain telah berperan menekan rezim yang berkuasa untuk melakukan perubahan, meskipun sebagian berhasil ditindas dengan kejam.

Sementara di Indonesia gerakan mahasiswa telahpun muncul sebagai salah satu gerakan sosial politik sejak dari jaman penjajahan sehingga hari ini. Dalam episode sejarah politik Indonesia gerakan mahasiswa muncul secara timbul tenggelam sebagai reaksi terhadap berbagai perkembangan politik yang berlaku. Pada masa Orde Baru gerakan mahasiswa mengalami depolitisasi dan represi secara massif yang mengakibatkan gerakan mereka nyaris lumpuh. Meskipun dalam berbagai kesempatan gerakan mereka bangkit melakukan penentangan terhadap rejim Orde Baru, namun berkalikali pula berhasil dipatahkan. Munculnya gerakan mahasiswa pada masa tersebut dipengaruhi berbagai macam faktor yang tidak dapat dipisahkan dari realitas sosial politik yang kompleks.

\section{Permasalahan Kajian}

Berdasarkan latar belakang di atas, maka permasalahan dalam kajian ini adalah, bagaimana dinamika gerakan mahasiswa di Indonesia pada masa Orde Baru dan bagaimana respon negara terhadap gerakan mereka? 


\section{Kerangka Teoritikal}

Kajian ini menggunakan teori hegemoni dari Antonio Gramsci. Gagasan Gramsci tentang hegemoni merupakan paradigma alternatif kepada teori Marxis tradisional yang dikritik sebagai fatalistik, deterministik, mekanistik dan reduksionis yang dianggap gagal memahami berbagai perubahan. Hegemoni adalah satu bentuk penyelenggaraan kekuasaan yang bersifat substil, lunak dan membujuk.

Hegemoni bukan merupakan hubungan dominasi dengan menggunakan kekerasan, melainkan satu hubungan persetujuan dengan menggunakan kepemimpinan politik dan ideologi yang dibina berdasarkan mekanisme konsensus. Williams (1960: 587) secara tegas mengemukakan hegemoni sebagai:

"Satu tatanan di mana cara hidup dan pemikiran kelompok tertentu menjadi dominan; di mana satu konsep realitas disebarkan kepada seluruh masyarakat dalam seluruh institusi dan kehidupan pribadinya, yang mempengaruhi seluruh citarasa, moralitas, kebiasaan, prinsip agama dan politik, dan seluruh hubungan sosial, terutama dalam pengertian intelektual dan moral."

Dengan kata lain, proses hegemoni terjadi apabila cara hidup, cara berfikir dan pandangan masyarakat bawah terutama kaum proletar telah meniru dan menerima cara berpikir dan gaya hidup daripada kelompok elit yang mendominasi dan mengeksploitasi mereka. Jadi, hegemoni terjadi jika ideologi daripada golongan yang mendominasi telah diambil alih secara sukarela oleh yang didominasi. Begitu hegemoni sudah tersebar dan meresap kuat ke dalam seluruh tatanan sosial melalui praktek bebas sehari-hari, praktek biasa daripada orang-orang yang hidup, yang merupakan masyarakat sipil, maka ini merupakan "konsensus spontan". Di mana kelas-kelas bawah menyetujui tatanan kehidupan sosial yang sesuai dengan kepentingan borjuasi. Mereka menerima ide-ide dan kepentingan politik kelas berkuasa seperti layaknya kepunyaan mereka sendiri.

Dengan cara apa hegemoni tersebut dilakukan? Gramsci mengkonseptualisasikan produksi persetujuan dicapai melalui penggunaan simbol-simbol, mitologi, institusi dan praktek-praktek kehidupan sehari-hari sebagai hegemoni. Hegemoni boleh terbentuk melalui berbagai cara dan pada berbagai wilayah kehidupan sehari-hari, melalui: Kebudayaan, kesenian, sekolah, universitas, keluarga, media massa, serta pembentukan wacana ideologi yang dilakukan secara terus menerus. Dengan kata lain, hegemoni dicapai melalui institusi-institusi masyarakat yang 
menentukan secara langsung atau tidak langsung struktur-struktur kognitif dan afektif masyarakat. Dalam konteks ini, bahasa memainkan peranan penting dalam merumuskan realitas serta melayani fungsi hegemonik untuk mengontrol berkembangnya wacana dalam masyarakat.

Selain itu, menurut Gramsci, superioritas ideologi itu haruslah juga memiliki akar-akar ekonomi yang kuat. Jika hegemoni itu merupakan etika politik, maka ianya haruslah juga bersifat ekonomik dan mempunyai landasan sebagai fungsi penentu, sehingga kelas yang sedang memimpin menjalankan aktivitas utama ekonomi yang ditentukan. Oleh karena itu, hegemoni merupakan bentuk kekuasaan yang menggunakan "kontrol moral" sebagai ujung tombaknya yang dikemas ke dalam satu sistem menyeluruh. Ringkasnya, satu kelas adalah hegemonik dan mampu mereproduksi hegemoninya sejauh ianya bukan saja membawa tujuan-tujuan ekonomi dan politik saja, tetapi juga kesatuan intelektual dan moral untuk berhadapan dengan semua perkara (Gramsci 1971: 181-182).

Hegemoni berlaku di dalam masyarakat sipil dan dominasi berlaku di dalam masyarakat politik atau negara. Hegemoni daripada kelas dominan dijalankan dalam masyarakat sipil dengan mengajak kelas-kelas yang berada di bawah atau subordinate classes untuk menerima nilai-nilai dan ide-ide yang telah diambil oleh kelas dominan dan dengan membina jaringan kerjasama yang berasaskan kepada nilai-nilai berkenaan (Simon 2001: 12-13). Dalam paradigma Gramsci, negara dan masyarakat sipil mempunyai sumbangan dalam proses hegemoni. Negara merupakan perangkat keras, yang akan menegakkan ketertiban melalui aparat koersifnya, yang terdiri daripada aparat penegak hukum, polisi, penjara, serta tentara.

Untuk mewujudkan hegemoni tersebut, menurut Gramsci, tidak boleh dilakukan sendirian, melainkan melibatkan konstelasi kekuatan sosial politik yang luas yang ia sebut sebagai "blok historis". Blok historis adalah hubungan resiprokal antara wilayah aktifitas politik, etik maupun ideologik, atau seperti dijelaskan oleh Gramsci sebagai, "perpaduan suprastruktur yang kompleks, kontradiktif dan tidak sejajar adalah cermin daripada sosial produksi" (Gramsci 1971: 336). Dengan kata lain, istilah "blok historis" merujuk kepada satu koalisi daripada berbagai kekuatan sosial (kelas-kelas) yang disatukan secara politik oleh seperangkat ide-ide hegemonik. Ide-ide itu melengkapi koalisi tadi dengan pandangan dunia yang koheren dan kepentingan bersama. Dengan demikian, satu blok historis yang berhasil, mengandaikan adanya kemampuan 
pemimpin blok untuk membuat ide-ide dan argumen persuasif sekaligus menguniversalkannya.

Dalam konteks negara Orde Baru, hegemoni yang dilakukan rejim secara nyata telah memberikan pengaruh penting terhadap kehidupan masyarakat, khususnya gerakan mahasiswa. Rejim tentara yang berkuasa yang disokong oleh unsur-unsur utama masyarakat lainnya secara menyeluruh telah berhasil mengontrol jalan fikiran dan tindakan masyarakat agar bersesuaian dengan cita-cita rejim. Sebagai akibatnya, kontrol dan hegemoni negara yang kuat terhadap proses politik telah menyukarkan civil society untuk mengembangkan autonomi dan kebebasannya dalam penciptaan masyarakat demokratik.

\section{Gerakan Mahasiswa dalam Tinjauan} Historis

Keterlibatan mahasiswa dalam politik di Indonesia memiliki akar sejarah yang panjang, mulai dari sebelum Indonesia merdeka sampai sekarang ini. Pada masa penjajahan gerakan mahasiswa dipelopori sejumlah kelompok kaum muda yang belajar di STOVIA (School tot Opleiding van Indlandsche Artsen) atau Sekolah Latihan Dokter Bumiputera di Jakarta dan mahasiswa-mahasiswa Indonesia yang belajar di negara Belanda yang mendirikan PI (Perhimpunan Indonesia). Tujuan organisasi tersebut adalah untuk membentuk kesadaran kelompok mahasiswa memperjuangkan Indonesia merdeka terbebas dari penjajahan Belanda (Poesponegoro dan Notosusanto 1984). Gerakan mereka berkembang cepat dan memberikan pengaruh penting terhadap perkembangan politik di Indonesia pada masa itu.

Setelah Indonesia merdeka, keterlibatan mahasiswa ditumpukan sepenuhnya kepada usaha-usaha untuk memenuhi kewajiban mengisi kemerdekaan dalam kehidupan yang normal dengan mencari ilmu. Mereka menjaga jarak dengan politik. Namun, perkembangan politik tahun 1950-an yang dinamik yang diwarnai pergulatan politik yang kuat telah menggiring dunia kampus terlibat dalam politik. Partai-partai politik berusaha membangun jaringannya dengan menanamkan pengaruhnya di dunia kampus. Karena itu kemudian muncul sejumlah organisasi-organisasi mahasiswa pada waktu itu yang berbasis "aliran" dan menjadi onderbouw dari partai politik, seperti HMI, GMNI, GMKI, CGMI, PMKRI, PMII, IMM dan lain-lain (Bachtiar 1968: 186-190). Kampus bukan saja tempat belajar, tetapi juga menjadi sumber rekruitmen partai politik. 
Pada awalnya organisasi-organisasi mahasiswa yang bercorak ideologis tersebut hanya diminati sebagian kecil mahasiswa yang ada di luar kecenderungan utama kehidupan kampus yang lebih bercorak rekreatif. Akan tetapi ketika negara cenderung menuju kekacauan, dan konflik ideologi semakin tajam, semakin banyak pula mahasiswa yang sadar dan peduli, yang kemudian mendorong mereka terlibat dalam organisasi-organisasi tersebut (Alimi 1993: 161-162). Setiap organisasi mahasiswa bersaing secara ketat berdasarkan kepentingan politik dan ideologinya. Sistem politik yang berkembang demikian bebas memberikan kesempatan yang luas kepada semua golongan untuk mengekspresikan kepentingan-kepentingannya.

Negara tidak memiliki wewenang yang kuat untuk mengatur dan mencampuri kehidupan kampus. Dunia kampus mengalami tahap politisasi yang demikian massif, yang menjadi lahan sosialisasi dan pendidikan politik yang menantang, sehingga memberikan bekal terhadap pendewasaan politik. Karena itu, tidaklah aneh kemudian jika berlaku polarisasi dan konflik-konflik yang meluas dalam kampus beradasarkan basis ideologi. Hal ini jelas menimbulkan perpecahan yang mendalam dan dapat mengganggu aktifitas akademik yang menjadi tujuan utama kampus. Situasi tersebut berlaku terutama pada masa
Demokrasi Terpimpin antara tahun 19591965 ketika Presiden Soekarno memerintah secara otoriter dan berusaha membungkam lawan-lawan politiknya, khususnya para politisi dan cendekiawan kritis di luar pemerintahan. Sebagian mereka adalah berbasis di kampus yang melakukan penentangan secara terselubung dan melancarkan kritik-kritik pada berbagai kesempatan.

Meskipun Presiden Soekarno mengecam kalangan akademisi kritis di kampus-kampus yang tidak sejalan dengan pemerintah, dengan mengatakan mereka sebagai "text book thinking", "intelektual keblinger" dan "kebaratan-baratan", namun sampai sejauh itu pemerintah masih menghargai kebebasan kampus dan tidak mencampuri urusan dan wewenang kampus, sehingga gerakan-gerakan mahasiswa masih cukup bebas, meskipun dalam batas tertentu tetap berhati-hati agar tidak berbenturan dengan kekuasaan. Keadaan kampus berkembang sangat dinamik sesuai dengan realitas di masyarakat.

Akan tetapi, keadaan tersebut berubah secara drastis seiring dengan berlakunya peristiwa G 30 S PKI yang berwujud percobaan kudeta yang gagal dilakukan PKI (Parti Komunis Indonesia) pada tanggal 30 September 1965. Tindakan Presiden Soekarno yang kurang tegas terhadap golongan komunis dan 
kepemimpinannya yang dianggap otoriter serta tidak mampu menyelesaikan berbagai permasalahan bangsa, membangkitkan gelombang perlawanan mahasiswa. Kelompok mahasiswa yang tergabung dalam berbagai organisasi mulai bergerak dan menyatukan diri dalam sebuah organisasi baru yang dibentuk pada tanggal 25 Oktober 1965, yaitu KAMI (Kesatuan Aksi Mahasiswa Indonesia), yang menjadi wadah seluruh organisasi gerakan mahasiswa Indonesia (Bachtiar 1968: 190206). Mereka kemudian berhasil menekan Presiden Soekarno mundur dengan memperoleh dukungan dari pihak militer terutama Angkatan Darat, sehingga memunculkan rejim Orde Baru.

\section{Konsolidasi Orde Baru}

Saat itu merupakan masa "bulan madu" hubungan mahasiswa dengan militer. Mahasiswa kemudian kembali ke kampus seraya melihat berbagai perkembangan yang berlangsung. Mereka merasa tugasnya telah selesai dan memberi kesempatan kepada pemerintah baru untuk bekerja. Sampai sejauh itu gerakan mahasiswa relatif memiliki kebebasan yang tinggi. Militer mulai berkuasa dan secara terus menerus melakukan konsolidasi kekuasaan dengan melakukan berbagai usaha "pembersihan" di semua segi kehidupan dari unsur-unsur "kiri" (komunis) yang masih ada, di samping juga memperbaiki kembali tatanan kehidupan negara yang kacau sebagai akibat warisan Orde Lama.

Tantangan utama Orde Baru adalah menstabilkan keadaan dan menata ekonomi negara yang porak poranda. Oleh karena itu, rejim Orde Baru melakukan berbagai langkah strategis dengan melakukan restrukturisasi di berbagai bidang. Di bidang politik, rejim mulai melakukan langkah-langkah depolitisasi seperti: Pembatasan partai-partai politik, menerapkan politik massa mengambang, mengeluarkan undang-undang politik dan pemilihan umum, menentukan monoloyalitas pegawai negeri, serta langkah-langkah kooptasi lainnya. Sementara di bidang ekonomi pemerintah mengambil kebijakan ekonomi "pintu terbuka" dengan mengundang masuknya investasi asing dan menggunakan bantuan luar negeri, serta melakukan pendekatan ekonomi yang lebih liberal dan bersahabat dengan dunia Barat (Mas'oed 1986).

Dengan cara itu, ekonomi Indonesia secara perlahan-lahan terintegrasikan ke dalam sistem ekonomi internasional yang didominasi oleh paham liberalisme kapitalisme. Strategi ekonomi diarahkan kepada terwujudnya suatu pertumbuhan yang tinggi yang diharapkan dapat menjadi pemicu munculnya peluang-peluang baru yang dapat menyerap tenaga kerja produktif yang melimpah. Melalui polisi 
yang digariskannya pemerintah Orde Baru berupaya untuk mewujudkan strategi pembangunan yang dapat memenuhi harapan riil masyarakat tanpa terganggu oleh hiruk pikuk politik. Namun di balik gagasan semacam itu mulai timbul dampak-dampak negatif seperti: Munculnya ketimpangan ekonomi, kemiskinan, ketergantungan kepada pihak asing, korupsi birokrasi, dan diabaikannnya hak-hak politik warga (Glassburner 1978: 137-170).

\section{Mahasiswa dan Kritik Terhadap Orde Baru}

Pada awal tahun 1970-an mulai muncul ketidakpuasan dan kritik-kritik di kalangan mahasiswa yang menilai pemerintah telah mulai menyeleweng dari cita-cita semula (Raillon 1985). Pemerintah dianggap tidak sensitif dan justru menimbulkan permasalahan baru. Mahasiswa meminta agar pemerintah bersikap jujur dan tegas dalam memberantas berbagai bentuk korupsi dan penyimpangan yang ada. Mereka menuntut adanya perbaikan kehidupan nyata masyarakat di tengah pertumbuhan ekonomi dan awal munculnya boom minyak. Namun sejauh itu, kritik mahasiswa dilakukan dalam konteks yang terbatas, dan lingkup yang lebih kecil yang sebagian diikuti berbagai tokoh mahasiswa yang sebelumnya terlibat dalam gerakan mahasiswa tahun 1966.

Protes mahasiswa tersebut sesungguhnya merupakan "peringatan awal" kepada "partner lama" tentang berbagai penyimpangan yang berlaku. Mereka belum bergerak secara massif, karena itu belum dianggap mengganggu keamanan nasional. Pihak militer yang berkuasa belum merasa perlu melakukan tindakan yang drastis dan lebih keras terhadap kritik tersebut. Mereka berhatihati agar tak memancing kemarahan mahasiswa dan bertindak lebih jauh. Sikap toleran penguasa boleh ditafsirkan bahwa mereka khawatir akan berlaku konflik yang luas dengan mahasiswa dan mengganggu konsolidasi rejim.

Tindakan mahasiswa ini menggambarkan munculnya keprihatinan baru dan keresahan yang berdasar di kalangan mereka akan arah pembangunan. Sebagai konsekwensinya pemerintah bersedia melakukan berbagai koreksi seraya menekankan bahwa mahasiswa hendaklah bersikap obyektif dan memberikan kesempatan yang lebih luas kepada pemerintah untuk merealisasikan program-programnya. Untuk menarik simpati mahasiswa pemerintah kemudian membentuk Komisi Empat Anti Korupsi pada bulan Februari 1970 (Raillon 1985: 80). Bahkan pemerintah berhasil meredam gerakan tersebut melalui cara yang lebih 
persuasif, dengan membawa permasalahan tersebut ke Dewan Perwakilan Rakyat (Parlemen) untuk dibahas menjadi suatu Rancangan Undang-Undang Anti Korupsi. Para mahasiswa merasa bahwa tuntutan mereka telah didengar.

Tetapi usaha pemerintah tersebut sia-sia, karena baik kerja-kerja komisi anti korupsi, pembahasan di dalam parlemen, serta berbagai koreksi, peringatan dan kritik keras mahasiswa justru tidak memperkecil berbagai penyimpangan yang berlaku. Korupsi semakin meningkat, ketimpangan masih terus ada, berbagai penyimpangan kekuasaan tidak bisa dibendung, pembatasan hak-hak politik juga masih terjadi, menyusul kemenangan partai pemerintah yaitu, Golkar (Golongan Karya) dalam pemilihan umum 1971. Karena itu, mahasiswa sekali lagi mengkritik pemerintah dengan lebih kuat lagi. Aspirasi mereka bergulir pada aspek keadilan sosial dan demokrasi yang lebih seimbang, sehingga merupakan kritik langsung terhadap pelaksanaan pembangunan.

Para mahasiswa kemudian mengarahkan kritiknya secara langsung terhadap berbagai proyek pemerintah selama ini seperti; buruknya pengurusan Badan Usaha Logistik (Bulog), korupsi di Perusahaan Minyak Negara (Pertamina), gaya hidup mewah para pejabat pemerintahan. Mereka secara khusus juga menyerang proyek mercusuar negara yaitu, Taman Mini Indonesia Indah, yang melibatkan isteri Presiden Soeharto, yang dianggap menghambur-hamburkan uang negara. Bahkan lebih keras lagi mereka menyerang dasar-dasar legitimasi Orde Baru. Berdasarkan kenyataan tersebut hubungan antara mahasiswa dengan pihak militer yang berkuasa mulai merenggang.

Mahasiswa berpendapat bahwa pemerintah tidak boleh dipercaya dan terus menerus menghindari tanggungjawab moralnya. Sementara pemerintah menganggap bahwa gerakan mahasiswa sudah mengarah kepada keadaan yang berbahaya, yang dapat membentuk opini negatif yang dapat menghancurkan legitimasi rejim. Karena itu, rejim yang berkuasa berhati-hati dan waspada terhadap mereka. Apalagi diduga ada upaya-upaya dari kelompok-kelompok tertentu untuk memanfaatkan gerakan mahasiswa untuk mencoreng pemerintah, menyusul ketidakpuasan sebagian elite politik terhadap rejim Soeharto.

Menjelang tahun 1974 momentum gerakan mahasiswa semakin meningkat yang kemudian mencetuskan "Peristiwa Malari" atau Malapetaka Januari tahun 1974. Pihak keamanan bertindak dengan cepat dan kemudian menahan tokohtokohnya. Sebagian tokoh mahasiswa diadili, bahkan dengan tuduhan subversif. Sementara sebagian lagi yang lain 
kemudian dibebaskan karena tidak cukup bukti. Pada bagian lain pemerintah juga mengambil tindakan yang lebih keras. Beberapa surat kabar memperoleh peringatan keras, dilarang terbit untuk sementara, dan beberapa lagi yang lain dilarang terbit untuk selamanya (Raillon 1985: 113). Beberapa intelektual dan tokoh politik, baik yang berada di maupun di luar kampus ditahan. Mereka dituduh bersekongkol dan melakukan provokasi terhadap para mahasiswa. Pemerintah juga kemudian mengeluarkan Surat Keputusan Menteri Pendidikan dan Kebudayaan No. 028/U/1974 yang melarang aktifitasaktifitas bersifat politik di kampus.

Kebijakan-kebijakan pemerintah tersebut jelas merupakan usaha represi yang dilakukan dalam rangka meredam gejolak di lingkungan kampus, dan menghambat gerakan mahasiswa sedemikian rupa agar tidak menjadi ancaman potensial rejim. Namun demikian, protes dan kekecewaan mahasiswa tetap meningkat seiring dengan ketidakmampuan pemerintah menyelesaikan berbagai permasalahan bangsa yang telah ada sebelumnya dan memanasnya situasi nasional dalam pemilihan umum 1977. Permasalahan tersebut seperti: Krisis Pertamina, pengadilan Sawito, kelaparan di Karawang, kecurangan pemerintah dalam pemilihan umum, pelanggaran hak-hak politik dan kebebasan rakyat, pemilihan para gubernur dan bupati di daerah, adanya anggota Dewan Perwakilan Rakyat yang dipilih pemerintah, serta berbagai praktek politik pemerintah yang inkonstitusional (Naipospos 1996: 27). Keadaan itu kemudian berpuncak dengan meletusnya peristiwa demonstrasi mahasiswa bulan Januari 1978, yang berhasil ditindas secara represif.

Beberapa tokoh mahasiswa ditahan, sebagian diantaranya bahkan kemudian diajukan ke pengadilan, sebagian yang lain dipenjara sebagian lagi dibebaskan. Sejumlah tokoh masyarakat dan intelektual juga ditangkap, namun kemudian dilepaskan, karena tidak ada bukti yang cukup. Bahkan pemerintah kemudian mengambil langkah-langkah lain yang lebih represif dengan; membekukan Dewan Mahasiswa di seluruh universitas, melarang majalah dan surat kabar-surat kabar kampus, merombak struktur tatanan organisasi mahasiswa dan tanggungjawab birokrasi di kampus dengan mencetuskan konsep NKK/BKK (Normalisasi Kehidupan Kampus/Badan Koordinasi Kemahasiswaan). Konsep tersebut bertujuan untuk menata kembali kondisi kampus agar berjalan normal seperti semula sebagai tempat belajar, dan mahasiswa mencari ilmu pengetahuan sesuai dengan yang diharapkan. 
Inti dari NKK/BKK adalah para mahasiswa dilarang dalam berbagai aktifitas menentang pemerintah atau terlibat dalam politik. Mereka yang terlibat dalam aktifitas semacam itu akan berhadapan dengan sanksi yang sangat berat, mulai dari skorsing sampai dengan pemecatan. Karena kampus bukan merupakan lembaga politik. Berdasarkan realitas tersebut birokratisasi kampus sangat terasa. Lembaga rektorat dan jabatan-jabatan struktural lain bukan mencerminkan kepentingan warga kampus, tetapi lebih merupakan perpanjangan kepentingan kekuasaan. Para dosen yang berani bersikap kritis kepada pemerintah, menentang pemerintah atau menyokong gerakan aktivis mahasiswa akan dihambat kariernya atau bahkan dipecat dari universitas. Pemerintah tidak ragu-ragu untuk menerapkan hukumannya terhadap mereka yang terbukti berkhianat kepada rejim.

Gerakan mahasiswa 1978 memberikan efek yang luar biasa kontrol negara terhadap gerakan mahasiswa. Berbeda dengan gerakan mahasiswa tahun 1974, yang membawa dampak represi terhadap gerakan mahasiswa, namun sampai sejauh itu masih ada "sedikit ruang terbuka" yang memungkinkan mereka bergerak. Dewan Mahasiswa yang merupakan lembaga perwakilan mahasiswa masih ada, pers kampus masih boleh bersuara, dan dalam batas-batas tertentu aktifisme mahasiswa masih dapat ditolerir meskipun dalam kontrol yang ketat dan sangat hati-hati. Gerakan mahasiswa 1978 berlangsung di bawah soliditas rejim yang semakin kuat dan tak ada tanda-tanda friksi di kalangan elite. Kebijakan pemerintah setelah gerakan mahasiswa 1978 menunjukkan kadar yang semakin represif. Gerakan mereka dihancurkan melalui serangkaian tekanan dan peraturanperaturan yang tidak memungkinkan bangkit seperti semula.

\section{Gerakan Mahasiswa 1980-an dan 1990-}

\section{an: Berlanjutnya Represi}

Di bawah kondisi yang semacam itulah aktifisme gerakan mahasiswa Indonesia semakin tenggelam. Rejim yang berkuasa secara terus menerus membatasi peran mereka dalam lingkup yang kecil seraya berupaya membalikkan orientasi mereka dari aktivisme dunia kampus yang penuh gejolak menuju dataran akademis yang tenang dan terkungkung. Hal tersebut ditempuh dengan pelbagai cara. Di satu pihak pemerintah secara terus menerus melancarkan proyek depolitisasi melalui serangkaian langkah kooptasi dan represi; sementara di pihak lain berupaya mengembangkan wacana umum, penanaman nilai-nilai dan keyakinan baru 
di masyarakat dengan mengintroduksikan idea-idea baru di balik jubah "pembangunan", yang pada gilirannya diharapkan memberikan pembenaran kepada rejim.

Sepanjang tahun 1980-an dan 1990an gerakan mahasiswa tercerai berai. Sebagian para aktifis mahasiswa mengalihkan aktifitasnya dalam bentuk "kelompok-kelompok studi" atau "kelompok diskusi" yang kecil dan terbatas. Karena itu, pada saat itu muncul banyak kelompok-kelompok studi mahasiswa di berbagai kota seperti: Jakarta, Bandung, Yogyakarta, Surabaya, Malang dan lain-lain. Mereka menyelenggarakan diskusi-diskusi rutin tentang berbagai masalah yang muncul dan menjadi arus utama dalam dunia ilmiah atau gerakan (Denny J.A. 1990). Sebagian aktifis mahasiswa yang lain terlibat dalam aktifitas-aktifitas di luar kampus tergabung dalam organisasi-organisasi nonpemerintah (NGO) dan melakukan kerja-kerja sosial pada tingkat mikro di masyarakat. Sebagian yang lain terlibat dalam jaringan kegiatan politik "bawah tanah" yang melakukan kontak-kontak terbatas dengan kelompok-kelompok atau pribadi-pribadi tertentu.

Sementara sebagian lagi yang lain terlibat dalam aktifitas-aktifitas kelompok keagamaan yang lebih terbatas dan eksklusif, baik yang ada di lingkungan kampus maupun di luar kampus. Keadaan ini berlanjut sampai era 1990-an, di tengah semakin kuatnya rejim Orde Baru. Pada pertengahan tahun 1989 dan awal tahun 1990-an ketika rejim Orde Baru melancarkan kebijakan "keterbukaan" secara terbatas, ada beberapa gerakan mahasiswa yang muncul dalam wujud protes-protes berskala kecil di beberapa kampus dan daerah yang bersifat lokal, namun tidak memiliki pengaruh yang penting, apalagi menggoyahkan kestabilan rejim (Lane 1991: 16-25). Meskipun gerakan semacam itu memancing sedikit perhatian, tetapi mayoritas mahasiswa di dalam kampus tidak tertarik dan menganggap sebagai abnormalitas dari situasi yang monoton.

Di tengah insiden-insiden semacam itu rejim Orde Baru tetap mencermatinya dengan baik, dengan berusaha secara terus menerus mengkooptasi gerakan mahasiswa atau juga memecah belahnya. Untuk mempertahankan kontrolnya pemerintah berupaya melakukan langkah yang berhatihati dan persuasif agar tidak memancing "konfrontasi terbuka" dengan mahasiswa. Namun demikian, sebagian mahasiswa tetap berusaha memperoleh momentum yang baik bagi kebangkitannya. Pada tahun 1990-an di tengah semakin kukuhnya rejim dan pembangunan yang semakin 
meningkat, banyak bermunculan kasuskasus yang menimbulkan praktek-praktek penyimpangan yang melibatkan aparat pemerintah. Para mahasiswa, terutama yang bergerak di luar kampus berupaya memanfaatkan masalah tersebut untuk menjadi isu "pemancing" untuk menyadarkan masyarakat.

Bahkan mereka mulai berhasil menggalang kerjasama dengan golongan buruh. Beberapa isu yang dikemukakan misalnya; isu buruh, penggusuran rumah warga, pedagang kaki lima, tukang becak. Tentu saja hal tersebut memancing respon balik dari rejim. Di beberapa kota besar seperti: Jakarta, Surabaya, Yogyakarta, Bandung, dan lain-lain para mahasiswa berhasil menggalang kekuatan bersama melalui protes kecil-kecilan meminta agar pemerintah tidak bertindak sewenangwenang. Tetapi sejauh itu tindakan pemerintah tetap keras dengan menekan gerakan mahasiswa. Berbagai gerakan yang muncul sepanjang tahun 1990-an itu nyaris tetap tak berkutik di bawah tekanan negara.

Kelompok oposisi dan berbagai kekuatan potensial penentang pemerintah terus ditekan sampai pada batas yang tidak memungkinkan mereka bergerak. Pemerintah tetap konsisten mengambil langkah-langkah tidak popular di tengah tuntutan rakyat yang semakin sadar.
Namun di samping itu pemerintah tahu bahwa kondisi umum gerakan mahasiswa sesungguhnya terpecah belah. Berbagai organisasi ekstra di luar kampus seperti: HMI, PMII, PMKRI, GMNI, GMKI, IMM dan lain lain yang menjadi tumpuan sebagian aktivis mahasiswa dalam mengasah naluri dan minat aktifismenya justru sudah sejak lama dikoptasi pemerintah.

\section{Kebangkitan Mahasiswa dan}

\section{Runtuhnya Orde Baru}

Keadaan di atas berlangsung hingga tahun 1997 ketika Indonesia mengalami krisis ekonomi yang berat. Berbagai kalangan mulai mempertanyakan ketidakmampuan pemerintah. Para mahasiswa kemudian bergerak dan mulai turun ke jalan-jalan melakukan demonstrasi di berbagai kota besar di Indonesia. Gerakan-gerakan tersebut juga memperoleh simpati dan dukungan dari masyarakat luas yang pada puncaknya berhasil menekan Presiden Soeharto mundur pada tanggal 19 Mei 1998.

\section{Mundurnya Presiden Soeharto} menandai era baru politik Indonesia yang dikenal sebagai "Era Reformasi". Pada masa ini politik Indonesia berkembang secara dinamik dan mengalami proses demokratisasi. Sistem politik yang 
sebelumnya otoriter berubah menjadi terbuka yang ditandai dengan munculnya berbagai kekuatan-kekuatan baru, baik dalam bentuk partai-partai politik, kelompok-kelompok kepentingan, atau kelompok-kelompok penekan atau berbagai organisasi baru yang lahir. Masyarakat dapat mengemukakan pendapatnya dengan bebas, pers dan media massa bergerak nyaris tanpa sensor. Ringkasnya masyarakat Indonesia mengalami suatu "euforia kebebasan".

Dalam keadaan demikian mereka harus berhadapan dengan kebebasan mereka sendiri, yang tidak jarang memunculkan konflik-konflik terbuka di masyarakat. Berbagai permasalahan baru muncul di masyarakat. Di bidang politik pertikaian antara elite politik terus berlangsung, korupsi semakin meluas, penegakan hukum tak sepenuhnya terwujud, reformasi birokrasi tersendatsendat. Akumulasi persoalan yang menumpuk menyebabkan transisi politik tidak berjalan lancar dan proses demokratisasi mengalami beberapa hambatan. Dalam masa yang singkat selama masa transisi tersebut Indonesia mengalami gejolak politik yang keras yang ditandai dengan tiga kali pergantian kekuasaan secara tidak normal. Dari Soeharto ke Habibie, kemudian
Abdurrahman Wahid dan Megawati Soekarno Putri.

Hegemoni negara yang semula tertanam begitu kokoh dan mapan dengan sendirinya berantakan. Dinamika politik yang berlaku telah menimbulkan konteks baru di mana masyarakat relatif menjadi kuat. Distribusi kekuasaan yang semula terkonsentrasi di sekeliling Soeharto dan para pembantunya, kini lebih menyebar di kalangan berbagai kekuatan, terutama partai-partai politik. Para tokoh partai politik dan berbagai kelompok strategis inilah yang menjadi elite-elite politik baru Indonesia, yang memiliki peran kuat mempengaruhi situasi negara.

Di tengah proses peralihan bangsa yang melahirkan berbagai dampak luas mereka berhasil menempatkan posisinya sebagai "patron-patron baru" dalam politik. Lebih dari itu, pola konflik yang sebelumnya terjadi antara kepentingan negara dengan nonnegara, kemudian lebih berdimensi luas, bukan hanya vertikal tetapi juga horizontal antar kelompok. Sehingga sifat persaingan kepentingan tidak lagi terkonsentrasi dari atas, tapi beragam dan meluas yang melibatkan pendukung partai-partai politik besar.

Dalam konteks ini, elite-elite partai politik dan kelompok-kelompok politik penting lainnya telah berhasil mempengaruhi dan menggerakkan 
masyarakat dengan berbagai cara, termasuk memanipulasi kelompokkelompok di masyarakat dan gerakan mahasiswa. Para elite politik tidak raguragu memanfaatkan jaringan mahasiswa untuk mendukung segala aktifitas politiknya, baik melalui "aksi-aksi damai" hingga aksi demonstrasi dan kekerasan. Berbagai gerakan mahasiswa terbukti memiliki kaitan dengan kepentingan eliteelite tertentu baik secara langsung maupun tidak langsung.

Dalam konstelasi politik yang berubah-ubah, berbagai gerakan mahasiswa tidak jarang terjebak dalam kepentingan elite politik atau minimal memiliki kaitan dengan agenda elite-elite tertentu, sehingga mereka berlaku partisan. Gerakan mahasiswa yang ada, kini sebagian ada yang digerakkan oleh kepentingan elite-elite dimaksud untuk mencapai tujuan-tujuan politik tertentu. Posisi dan kepentingan elite politik memberikan pengaruh cukup penting terhadap eksistensi gerakan mahasiswa pada era reformasi.

\section{Kesimpulan}

Dalam membincangkan gerakan mahasiswa di Indonesia pada masa Orde Baru, ada beberapa kesimpulan yang dapat dikemukakan. Pertama, dinamika gerakan mahasiswa di Indonesia pada masa Orde Baru hakikatnya berkait erat dengan kondisi sosio-politik negara. Gerakan mereka muncul bersamaan dengan usahausaha pembaruan, baik dalam bidang politik maupun ekonomi dan sekaligus merupakan respon pada proses pembangunan. Dalam bidang ekonomi, wujud pelaksanaan ekonomi yang tidak adil dan seimbang. Sementara dalam bidang politik, gerakan mahasiswa amat dipengaruhi oleh wujudnya sistem politik yang menindas, yang membatasi ruang kebebasan.

Kedua, pasang surut gerakan mahasiswa sangat dipengaruhi oleh perubahan karakter rejim. Pembangunan yang berlaku pada masa Orde Baru, bagaimanapun, dalam beberapa tahapan, telah menimbulkan evolusi terhadap kewujudan rejim. Sejalan dengan berjalannya waktu dan keberhasilan pembangunan di berbagai bidang, maka sejak awal tahun 1980-an rejim Orde Baru menunjukkan reputasi dan keperkasaannya, yang disertai dengan pemusatan kekuasaan yang lebih nyata di tangan Presiden Soeharto. Keadaan ini menjadikan rejim 
semakin represif, tanpa memberikan kelonggaran sedikitpun kepada kekuatan oposisi, khususnya mahasiswa.

Ketiga, dalam menjelaskan respon negara kepada gerakan mahasiswa, kita mengenali adanya pelbagai bentuk, tetapi hakikatnya semuanya bersifat menindas. Tindakan itu mulai dari pelarangan, kooptasi sampai kepada hegemoni. Keempat. sebagai konsekuensi dari respon negara yang keras dan tersusun terhadap gerakan mahasiswa membawa beberapa impak penting, yaitu: Gerakan mahasiswa secara umum mengalami kemerosotan politik, kemalapan panjang, terkungkung, tercerai berai, kehilangan independensi, apatisme, dan hanya bertumpu kepada isuisu di kampus.

Namun demikian, projek hegemoni negara bukanlah berlaku tanpa penentangan sama sekali. Penentangan tersebut tetap ada, meskipun tidak cukup signifikan untuk menggoyahkan kelas yang berkuasa. Akan tetapi, keadaan menjadi berubah ketika Indonesia dihantam krisis ekonomi. Pemerintah Orde Baru yang gagal menangani krisis, segera memperoleh serangan dari masyarakat luas, khususnya mahasiswa. Mahasiswa secara terus menerus melancarkan demonstrasi yang berhujung pada jatuhnya rejim Orde Baru tahun 1998.
Pada akhirnya, daya tahan dan kuasa hegemoni itu ada batasnya. Ianya tidak mungkin berlangsung selamalamanya, sehingga pada tahap tertentu akan runtuh juga, kerana rakyat lambat laun akan sadar bahwa ia dihegemoni. Hal itu boleh berlaku, oleh sebab pelbagai pengaruh, baik yang bersifat eksternal maupun internal, yang memiliki impak luas terhadap kehidupan masyarakat. Pengaruh itu misalnya dalam bentuk; globalisasi, perkembangan pesat sains teknologi dan informasi, internet, media massa, kemajuan ekonomi, lingkungan politik internasional, munculnya ide-ide baru dan lain-lain, yang berhujung kepada pembentukan kesadaran di masyarakat. 


\section{DAFTAR RUJUKAN}

Alimi, Taufiq, "Kebijakan Pemerintah Terhadap Mahasiswa", Prospektif, No. 3, Vol. 5, 1993: 159-168.

Altbach, Philip G., "Gerakan Mahasiswa Dalam Dasawarsa Tujuh Puluh Dan Delapan Puluhan", dalam Philip G. Altbach (ed.), Politik Dan Mahasiswa: Perspektif dan Kecenderungan Masa Kini, (Terj.), Jakarta: PT Gramedia, 1988:1-18.

Bachtiar, Harsja W., "Indonesia", in Donald K. Emmerson (ed.), Studens and Politics in Developing Nations, New York: Frederick A. Praeger, Inc., Publishers, 1968:180-214.

Denny J.A., Gerakan Mahasiswa Dan Politik Kaum Muda Era 80-An.. Jakarta: CV. Miswar, 1990.

Glassburner, Bruce, “Indonesia's New Economic Policy and Its Sociopolitical Implications", in Karl D. Jackson and Lucian W. Pye (eds.), Political Power and Communications in Indonesia, Berkeley, California: University of California Press, 1978:137-170.

Gramsci, Antonio, Selection from the prison notebooks. Pnyt \& Terj. Hoare, Quintin \& Smith, Geoffrey Newell. London: Lawrence \& Wishart, 1971.

Lane, Max, 'Openeness', Political Discontent and Succession in Indonesia: Political Developments in Indonesia 1989-1991. Brisbane, Griffith University: Center for the
Study of Australian-Asian Relations, 1991.

Lipset, Seymour Martin, "Preface" in Seymour Martin Lipset, (ed.), Student Politics, New York and London: Basic Books, Inc., Publishers, 1967:vii-ix.

Mas'oed, Mochtar, Ekonomi dan Struktur Politik: Orde Baru 1966-1971, Jakarta: LP3ES, 1986.

Naipospos, Bonar Tigor, "Mahasiswa Indonesia dalam Panggung Politik: Ke Arah Gerakan Rakyat?", Prisma, No. 7, 1996: 17-33.

Poesponegoro, Marwati Djoened dan Nugroho Notosusanto, Sejarah Nasional Indonesia, Jilid V, Edisi 4. Jakarta: Departemen Pendidikan dan Kebudayaan, PN Balai Pustaka, 1984.

Raillon, Francois, Politik dan Ideologi Mahasiswa Indonesia:

Pembentukan dan Konsolidasi Orde Baru 1966-1974, Terj., Jakarta: LP3ES, 1985.

Simon, R., Gagasan-gagasan politik Gramsci. Terj. Kamdani \& Imam Baehaqi. Yogyakarta: INSIST Press \& Pustaka Pelajar, 2001.

Williams, G.A., The concept of 'egemonia' in the thought of Antonio Gramsci: some notes on interpretation. Journal of the History of Ideas, Volume xxi: 586599, 1960. 
32 JURNAL ILMIAH MIMBAR DEMOKRASI 